\title{
Legal Regulation of Procedural Options in Automatic Digital Systems of Courts of General Jurisdiction
}

\author{
Borisova V.F. ${ }^{1,{ }^{*}}$ Soldatkina O.L. ${ }^{2}$ Kalmazova N.A. ${ }^{3}$ \\ ${ }^{1}$ Department of Civil Procedure, Saratov State Law Academy, Saratov 410028, Russian Federation \\ ${ }^{2}$ Department of Informational Law and Digital Technologies, Saratov State Law Academy, Saratov 410028, Russian \\ Federation \\ ${ }^{3}$ English Language Department, Saratov State Law Academy, Saratov 410028, Russia \\ *Corresponding author. Email: vfb2709@yandex.ru
}

\begin{abstract}
The article deals with the analysis of modern statutory regulation of procedural options of automatic digital systems used in courts of general jurisdiction. The authors' conception is connected with distinguishing the services, applied in civil litigation in GAS "Pravosudie" (ГАС «Правосудие») and Complex Information System of Courts of General Jurisdiction (CIS CGJ), (КИС СОЮ), research of their legal framework, description of technical and legal faults of options. Thus it is possible to classify procedural options according to their term, degree of existing statutory manifestation and the level of effective functioning. We have arrived at the conclusion that GAS "Pravosudie" has options, manifested in legislation and full-fledged functioning as well as options which do not have statutory regulation, but exist in the system. There have been enumerated progressive changes in the sphere of functioning of procedural options in (CIS CGJ) and necessity of digital regulation of some procedural issues like procedure of accepting application, submitted electronically, the process of presenting evidence within the system of electronic files and application of videoconferencing, filing "electronic" case, enjoyment of procedural rights and obligations of the litigants in electronic format. We have suggested the ways of technical and legal improvement of automatic digital court systems.
\end{abstract}

Keywords: state automatic system "Pravosudie” (GAS “Pravosudie”), Complex Information System of

Courts of General Jurisdiction (CIS CGJ), digitalization of justice, procedural options, informatization of

courts, electronic case

\section{INTRODUCTION}

E-justice develops in the following basic directions: implementation of new technologies and software tools (artificial intelligence, Big Data and cloud technologies) resulting in digitalization of the greatest part of communication. These directions (levels) are characterized by lack of strict borders of modernization of legislation and absence of legal definitions of the basic terms.

The application of programme-based, targeted method of governmental e-justice digitization policy is connected with the Federal Digital Program "E-Justice Development of Russian Court System in 2013-2020" [1], “The Strategy of Court System Digital Policy in 2020-2030"[2], "The Strategy of Regulation of Artificial Intelligence and Robotechnics till 2030". Diversity of programs allows simultaneous introduction to court system of a multiplicity of automatic digital systems with underdeveloped legal framework. Thus the issue is urgent and provides for comparative research of procedural options applied in state automatic system GAS "Pravosudie" and Complex Information System of Courts of General Jurisdiction (CIS

CGJ) to state technical and legal faults and ways of legal modernization and to work out proposals of improvement of Russian Federation Code of Civil Procedure (CCP RF), (ГПК РФ) to eliminate difficulties of e-justice development [3].

\subsection{Research methods}

For this article there were applied general research methods of analysis, synthesis, forecast, and special cognitive methods like comparative legal research and formal logical research. There is a high degree of academic novelty in the method of intellectual design where one can combine technical and legal characteristics 
of procedural options that function in automatic digital systems: GAS "Pravosudie”, CIS CGJ.

\subsection{Results}

We have systematized procedural options of two basic available automatic digital courts of general jurisdiction: GAS "Pravosudie" and CIS CGJ. There has been formulated an original classification of procedural options concerning time of action, degree of representation in the rules of law, level of efficiency. There follows the list of technical and legal faults of procedural options in GAS "Pravosudie":

- submission of both electronic and paper files;

- lack of statutory regulation of the consequences of electronic submission to courts;

- lack of "procedural" reaction to electronic file from the court;

- limited number of documents, submitted electronically; - necessity to use special programmes to convert files from one format to another;

- lack of legal definition of the term "electronic evidence" as well as order of its provision and rules of its examination by court;

- lack of legal provisions in connection with permissibility and order of examination of evidence during the trial using videoconference format;

impossibility of access to case files through the system and absence of the case files in electronic form;

- impossibility of an individual (from the parties to the case) to receive copies of court rulings, through information telecommunication system "Internet", even if they have been created electronically;

- gap in legislation of the consequences connected with the absence of the records of the audio-version of the hearing.

The analysis of CIS CGJ revealed the following:

- automatic processing of electronic documents submitted to courts allows to in-form parties on time about the status of the case, to form electronic files of the case, to send subpoenas;

- access to the case allows to read the materials of the case. When the access is permitted there is presumption of reading the case without access denial, term of access, possible differences between paper files and electronic ones. Nowadays presumption has no statutory regulation; - receipt of access to the case files gives the rights to the parties to receive copies of electronic files, signed by forced qualified signature;

- statutory gap concerning lack of the term "technical refusal" of the documents, submitted electronically, and the rules of its procedural formulation;

- recording audio and video material of the hearing using special program including automatic enclosure of the recording to the records of the case hearing to allow usage of the recordings in higher courts, and as the evidence in other trials;
- statutory solution of the problem of examination of written evidence and exhibits in the videoconferencing hearing.

\subsection{Discussion}

\subsubsection{Procedural options of the existing automatic digital systems in courts of general jurisdiction}

Review of technical decisions worked out within the framework of digital justice has revealed existence of parallel digital systems with different technical decisions and sets of "procedural" options. The latter mean those services, which allow the parties of civil litigation to exercise their procedural rights and obligations.

Review of information systems allows to classify different procedural options on different foundations:

1) according to the time of action, concerning existing and prospective options;

2) according to statutory rules, concerning legislatively regulated and non-regulated options;

3) according to the level of successful functioning, concerning fully functioning, under functioning and nonfunctioning options.

Necessity of statutory regulation is defined through analysis of procedural options of automatic digital systems.

\subsubsection{Procedural Options of GAS "Pravosudie"}

GAS "Pravosudie" is geographically distributed automatic digital system created to form integrated area of courts of general jurisdiction and the system of Judicial Department of the Supreme Court. This system includes legal provisions and fully-fledged functioning of the following options:

1. Submission of the pleading, complaint, representation and another documents electronically, in the format of efile, signed by electronic digital sig-nature through the court site form (Article 3, 322, 378 CCP RF etc.)

Faults of "electronic" enjoyment of the right to court submission are connected with additional submission of paper files, obligation to print submitted documents and enclosures and to confirm the submission to the defendant. (Article 132 CCP RF). There are inconveniences when the divorcing spouses have the same address and send each other the copies of the documents by mail. A separate problem is lack of legal provisions in case of "technical refusal" to accept the pleading if the form is inconsistent with the requirements according to the RF Supreme Court Judicial Department Order of December 27, 2016, № 251 [4].

2. Electronic submission by the individuals, parties to the case of the documents filed by themselves or by other 
individuals or bodies or organizations. (Article $35 \mathrm{CCP}$ $\mathrm{RF}$ ).

One should choose in the menu "pleadings", "motions", "objections" the variant of the document according to his aim and content. Thus the individual can submit files through internet and require to secure the claim, to change the claim, to waive a claim or appeal, to admit a claim, to settle, to abolish default decision, to formulate the opinion, to adjourn a hearing, to challenge, to issue an enforcement writ. "Electronic" format is used for the motions to discover documents, to approve settlement, to halt execution, to reactivate procedural periods, to read case files and records of the trial. Courts sites allow to argue the claim, appeal, cassational appeal, private complaint, and arguments concerning the court order. Every document may have an enclosure of PDF electronic documents. The list of variants mentioned above is not absolute as the individual can submit a document which has not been mentioned through the tab "Additional". If the documents were submitted electronically, the court has the right to request the original ones. As for the technical faults it is necessary to mention a limited number of documents in PDF format, necessity to use file conversion programs from one format into another, lack of communication from courts (except confirmation of document receipt). As for legislation, there is no legal definition order of pro-vision and rules of court examination of "electronic" evidence and their additional submission in paper form.

3. Preparation of electronic court orders signed by the judge with forced qualified electronic signature. Preparation of such orders presupposes additional filing in paper form. (Articles 12, 197, 224 CCP RF).

On the site of courts of general jurisdiction one can input the number of the case and find the texts of court writs without due authentication to read. The requirements to the formats of court orders sent to be enforced in the form of electronic document are set by the Government of the Russian Federation. (Article 130, CCP RF).

4. Electronic information of the individuals, participating in the case provided by Article $35 \mathrm{CCP}$ RF affected through text message in the subsystem "Judicial Procedure and Statistics" GAS "Pravosudie".

Besides, individual participants to the case may acquire information about the trial from court sites through the lists of scheduled court hearings, and information about the stage of the trial and court rulings.

5. Sending by court of the electronic court order to be enforced by enforcement officer on the request of the claimant (Article 130 CCP RF).

Since writ proceeding cases are in the competence of the justices of the peace, electronic interaction occurs through the module ПИ «Амирс» GAS "Pravosudie" [5].

6 . Concurrence in the request about protection of rights and legal interests of the individuals through filling up the form of the official court site in information telecommunication network "Internet" or in GAS "Pravosudie" (Article 244.20 CCP RF).
The following procedural options have statutory recognition but function incompletely within GAS "Pravosudie":

1. Receipt by the participants of the case of the court rulings copies through in-formation communication network "Internet" and created in electronic form (Article 35 CCP RF).

Electronic files of Court decision with the permission of the parties may be available on the official court site in information communication network "Internet" with limited access within 5 days after the day of its creation (Article 214 CCP RF). In fact court decisions are available on the sites of courts of general jurisdiction in the Word format with partly private data and they are publicly available [6]. This decision is not authenticated properly and cannot be used as enclosure to the appeal. Court decision is not available on the court site if it is prohibited by Federal law, Article 15, 22.12.2008 №262 Ф3 (To Provide Access to the Information about the Activity of Courts in the Russian Federation) [7].Thus procedural right of individual participants to the case is exercised not fully.

2. Video conferencing and online translation of court hearings.

Video conferencing (Article 155/1, 229 CCP RF) is used to provide hearing participation of the individuals, who are parties to the case, their representatives, witnesses, interpreters, experts, specialists if they are at some distant location. However subsystem "Video conferencing" GAS "Pravosudie" does not always function properly, there may occur technical problems and difficulties, connected with time difference in various climatic zones. There is no legislative regulation of the issue concerning admissibility and order of evidence examination during the court hearing of video conferencing. Article $10 \mathrm{CCP}$ RF includes the issue of Internet translation of the hearing with the court's permission. However existence of the system in GAS "Pravosudie" does not mean its application to the full extent. The reason is final out-put of the communications line, insufficient and technically unequal equipment in the regions and lack of skilled specialists to operate the system.

3. Audio records of court hearings (Article 228, $230 \mathrm{CCP}$ $\mathrm{RF}$ ) is done through the subsystem "Judicial Records Management and Statistics" (GAS "Pravosudie") except hearings in camera. CCP RF does not regulate the consequences of absence of audio records or its parts and does not prioritize records or audio records of the court hearings if they differ.

"Electronic case" is procedural option presented in GAS "Pravosudie" without statutory regulation. At present it is impossible to read case files through on-line services, to receive an attested copy of court ruling etc. From the technical point of view access to the files of "electronic case" is denied as paper civil cases are not converted in electronic form and the basic form is paper one [8]. Scanning is time-consuming. Thus application of digital justice demands creation of original electronic cases without transitional paper stage. 
Another problem is that now lack of full statutory regulation of procedural options is compensated by multiplicity of department documents, creating legal chaos and contradictions in interpretation.

\subsubsection{Procedural Options in CIS CGJ}

At present CIS CGJ is applied and is at the same time a pilot project in the courts of general jurisdiction in Moscow. There is a uniform technological platform, which basic goals are provision of electronic interaction between courts and parties, courts and departments administering law, and electronic interaction between all levels of court system [9].

Statutory regulation of procedural options of CIS CGJ is based on CCP RF. Expertise is provided in two instructions: instruction to the service "Electronic submission to court" and instruction to the service "Access to electronic court files".

Procedural options of CIS CGJ system are the following:

1. Automatic identification of the territorial jurisdiction of the case.

2. Finding support information on the case, including the judge, hearing the case, stages of the trial, parties, date, time and courtroom. Processing files submitted electronically through private profile and court site is completed automatically, including the changes of the status of the case hearing (in contrast to "GAS Pravosudie").

3. Calculator of state duty forms the receipt automatically depending on the character of the claim and the price of the suit. However despite the fact that CIS CGJ has appeared later than GAS "Pravosudie" electronic payment of state duty in the Personal Account is still absent.

4. Notification of parties to the case is optimized through interaction of CIS CGJ with Russian Post. Since 2019 it is possible to send out electronic registered letters which solve the problem of the guarantee of reading the letter by the addressee.

5. Electronic submission of procedural files through "Personal Accounts" is done through filling up the forms similar to the ones of GAS "Pravosudie". If it is necessary the enclosed documents are signed electronically (in sig format).

If the claim was submitted electronically the plaintiff must send to the defend-ant copies of submitted documents, send to the court original documents in paper form or their registered copies to form the "paper" file. Printing of the documents from the system is done by the court staff; this work increases not only pressure but also additional financial spending. In this sense there is no progress of full conversion to "electronic case".

However the researched procedural option has been improved: the initial registration of each document submitted to court includes barcoding. This barcode allows to "assign" the document to the concrete case and to create its electronic image. Instruction to the service "Electronic Submission of Documents to Court" includes the list of documents which submission must include the number of the case to adhere it automatically to the electronic court documents created earlier. The document may have one of the statuses:

- "registered", assigned after successful submission of the document to the court;

- "attached to the case", assigned when there was created attachment of the submitted document to case files;

- "filed initial document", assigned when a new document was filed on the basis of submitted claim;

- "technical refusal, assigned when attachment of the document was refused and the reason of refusal is stated in the field "Comments"[10].

If we compare submission through GAS "Pravosudie", the document may be assigned the status of "registered", "dismissed", "passed on to the judge consideration".

Therein submission of documents through automatic systems is connected with assignment of states, which are not regulated in legislation on civil procedure. CCP RF lacks the concept of "technical refusal" or "dismissal of the claim", as well as the rules of its procedural form.

6. Access to the case files is given after sending through the system the motion of gaining access. According to the classical scheme of statutory regulation the motion is the enjoyment of right to read the case files. However within CIS CGJ submission of the motion results in 3 important procedural consequences:

1) after sending the request the claimant agrees to the fact that access gaining means reading original case files. In fact there is introduction of new presumption of several components. Access to the case presupposes that electronic files have full set of procedural documents, including instruments of evidence and court procedural documents. The issue of differences between paper and electronic files is not dis-cussed and the consequences of the difference are not known. Another important is-sue is the refusal of gaining access or expiry of time of access. The term of access and the reasons of access denial have no either statutory regulation or by the Instruction to the service "Access to Electronic Case Files of Court". There is no any other regulatory document. Shortage of information when presumption is used predetermines infringement of enjoyment of right to read case files;

2) gaining access to case files allows to receive information about the changes of the case status by email and it is very convenient for the user. Such a possibility may be distinguished as independent procedural right of the parties;

3) gaining access to the case files gives the right to get copies of electronic documents, signed by forced electronic signature.

Thus there is complex of interdependent "electronic" and traditional procedural rights of the parties of the civil litigation which must be regulated.

To read the case with the open access can be supplemented through the following tabs: general information, status of the case, court hearings, documents, video recordings of the court hearings (if any). Analysis reveals that within CIS CGJ there is successful development of digital justice 
(filing of "electronic" case, access to it, enjoyment of a wide range of procedural rights in electronic format).

7. Audio and video control of court hearings.

CIS CGJ allows to record in program complex and automatically adheres the recording to the court hearing records. An advantage of the system to compare with GAS "Pravosudie" is gaining of access of the parties to the court hearing records through Personal account.

8. Videoconferenceing and online translation of court hearings.

Videoconferencing allows court hearing participation to the individuals, representing parties, like convicts, staying at the places of detention, their representatives, witnesses, experts, specialists, translators, staying in the rooms of the court. These individuals may explain the case, file motions, answer the questions. As the problem of examination of evidence in a videoconference hearing has not been solved, enclosing and examination of exhibits, written and any other evidence is excluded. Also according to procedural rules it is not allowed to videoconference through Skype from any other places except official institutions (like FSEP (ФСИН), courts), their employees must guide the process.

It should be noted that the option of online court hearing translation is effective, except the cases which translation is prohibited by law.

8. Besides the main procedural options CIS CGJ has supplementary ones, sup-ported by Portal of United Information Media of Moscow Justices of the Peace; it includes patterns of claims and motions, explanations of the main stages of the trial.

In general, comparison of procedural options of GAS "Pravosudie" and CIS CGJ demonstrates that identical procedural rights and duties are executed technically much better by Moscow courts. There is effective functioning of the options of file submission, reading the file, receipt of registered court rulings, videoconferencing and audiorecording. However new electronic options supporting civil litigation demand statutory regulation. The least represented in the process of electronic modernization both technically and legally is the process of providing evidence. Automatic digital systems of courts do not have options to enclose to case files such instruments of evidence as video and audio recording, electronic evidence. Application of such instruments could have made the process of court examination of evidence much easier.

\subsubsection{Results}

To sum up it is necessary to state the ways of improvement of statutory regulation of digital procedural relations:

- to create the framework of legal rules concerning acceptation or denial of the claim submitted electronically; - to regulate the order of provision, enclosure, authentication and examination of electronic evidence and electronically submitted evidence as well as the order of examination of exhibits and written evidence during the videoconferencing hearing;

- to regulate the consequences of audio records of court hearing and its parts or differences between hearing records or its parts and its audio variant;

- to work out legal framework to apply newly created presumptions of "case ac-cess" and "electronic notification".

On the technical and legal levels automatic digital court systems may be improved through:

- placement of court definitions concerning claims left without changes, returned or denied (through personal accounts without broad access);

- creation of platform for rapid correction of faults of the claim and its subsequent electronic submission;

- creation of technical and legal possibility to pass to court audio and video recordings evidence through automatic court systems that will make easier the process of their enclosure and examination during the court hearing;

- provision of much broader possibilities to use electronic documents and wider status of scan-copies and electronic signatures, minimizing "paper" stage of procedural documents;

- working out of technical order for automatic calculation of state duty and its payment through "Personal Account". Speaking about material and technical resources it is necessary to eliminate un-equal equipment of regional courts with computers and eligible network connections on the basis of complex program operating both within judicial system and the system of Federal service of court bailiffs. It is not ergonomic to double services of different automatic digital systems used simultaneously by courts of general jurisdiction. It overloads the court system and there arises urgent issue of the uniform strategy of digitalization of court system that will allow to create single digital media of justice.

\section{ACKNOWLEDGMENT}

The study was carried out under financial support of the Russian Foundation for Basic Research (RFBR) within a research project № 18-29-16111.

\section{REFERENCES}

[1] RF Government Ruling of 27 December 2012 №1406 (edit. Of 25.12.2019) “About the Federal Target-Oriented Program "Development of Russian Court System in 2013-2020" // Collection of RF Legislation. 2013. № 1. Art. 13.

[2] Conception of Information Policy of Court System in 2020-2030 (approved by The Council of RF Judges 05.12.2019) // Access from Advisory Legal System “Con-sultant Plus" (Retrieved on 07.02.2020). 
[3] V.F. Borisova, S.F. Afanasiev (2019), Realia and Prospects of Civil E-Justice Legal Regulation. In: Popkova E. (eds) Ubiquitous Computing and the Internet of Things: Prerequisites for the Development of ICT. Studies in Computational Intel-ligence, vol 826. Springer, Cham. pp. 403- 405.DOI: https://doi.org/10.1007/978-3-030-13397-9_47.

[4] Order of Court Department of the Supreme Court of the Russia Federation of 27 December 2016. № 251 // Bulletin of Acts of Court System. 2017. №2.

[5] E.V. Markina. Complex Automation of Writ Proceedings in GAS "Pravosudie" // Legal Computer Studies. 2009. № 2. P. 60-63, 66.

[6] T.A. Kalent'eva. Information Accessability of Court Rulings: Myth or Reality? // Bulletin of Tatishchev Volzhskii University. 2008. № 2. P. 179-180. DOI: 10.24412/FfPU_zjZ67Q

[7] Federal Law of 22 December 2008. № 262-Ф3 (edit. on 28.12.2017) "About Pro-vision of Access to the Information about Activity of Courts in Russian Federation" // Collection of RF Legislation. 2008. № 52 (part. 1). Article 6217.

[8] N.G. Shurukhnov. Stages of Digitalization of Direct Proceedings of Investigative and Another Procedural Actions // Bulletin of Tomsk State University. 2018. № 436. P. 252-255. DOI: 10.17223/15617793/436/31.

[9] URL: https://www.mos-gorsud.ru/is-and-db (Retrieved on 05.02.2020 г.).

[10] Instruction to the Service "Electronic Filing to Court"

URL:https://mos-gorsud.ru/getGalleryImage/96298c9a00a2-485d-b9e8-a186529a12c3 (Retrieved on 06.02.2020). 